\title{
After the snow
}

Who will save the servants?

\section{N. Simms}

Maybe it's the background noise of my husband's resonant snoring that conjures up the images of falling snow hitting the ground with dull, forceful regularity. It feels apt that I wake in a cold sweat, given the subject of my sepia-tinted dreams.

My husband stirs. "The same dream again?" he asks from his prone position, his weary concern tempered with impatience as I cross to the window. He cedes to the pillow without waiting for a reply and, as always, my faint hopes are scattered by the hurricane winds whipping half-seen objects silently down the desolate street.

It wasn't the ones you'd expect. It wasn't the sheep or the crops. It wasn't even the humans we managed to grow once the ethical barriers had crumbled to the tide of discovery. It was the first ones, the bacteria. It's all so far in the past now that most people think that the bacteria have always been here.

Acclaim and blame lie with Saint Craig Venter, double Nobel laureate, entrepreneur and genetic pioneer. He's mentioned in the same breath as Gandhi, Darwin and Einstein. With Trump, Gates and, more recently, with our very own Henderson. Back then they were having trouble with global warming, but amid spiralling population growth and struggles to keep hold of financial reins as a global recession bucked bankers out of buildings, they could do nothing about climate change.

Fortunately that wasn't the end, because geneticists managed to manufacture a bacterium's genome by sticking together small segments of DNA. It seems so staid considering that in a few hours I'll be using a Henderson localized DNA-adjusting kit to choose the perfume I'll emit from my pores today, but back then it was phenomenal stuff. Despite all our advances, Henderson will never be canonized. The church fell not long after Venter's time and now all we have are thousands of apocalypse-chasing groups, a mish-mash of old, dead religions. There's little comfort to be found there.

The simple bacterium mimicked was Mycoplasma genitalium. The smallest known free-living natural bacterium. And the copied genome was to become the first genuine artificially created life. Not exactly intelligent, but alive and capable of reproducing. How did they do it? At the researchers' behest, corporations made hundreds of specific sections of DNA, each one just a few hundred bases long. Enzymes stitched the overlapping fragment ends together, creating a carbon copy of the genome of the bacterium. Two long years later, after labs had twice been$$
\text { (1) }
$$

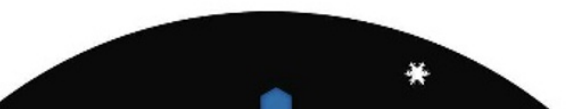
so numerous that fires started spontaneously in their oxygen-rich surroundings. They turned back the clock for us. They became a part of life, doing innumerable crucial tasks. I even had some to keep our apartment on the right side of carbon neutral. We let the bacteria do our job for us, and they did it well.

Atmospheric carbon levels dropped, the ice caps stopped melting, the seas stemmed their inevitable rise and the wildlife in the seven worldwide protected zones began to reproduce again. It was too late for the corals and most of the fish, but we have new fish now. We did have new fish.

"We should have known,"

I tell the bleak early-morning winds, their strength disguised by the noise-dampening glass. Increased temperatures mean that most mornings bring hurricanes nowadays. He's fallen asleep again, I think, he won't hear me. He hardly ever listens even when he's awake.

"Alice," he says, shading his eyes to see the silhouette of my body, highlighted by the reflection of street lights in the fierce eddies and swirls of the air behind the window. "It's four. It's not snowing. It will never snow. Now come back to bed."

We took every precaution to stop the bacteria from mutating. But that meant that when they started to die, they couldn't adapt. We still don't know what's killing them. And now the world is worse than it's ever been.

"Maybe we won't be able to do it. Maybe we'll have to do what they failed to do back then and cut emissions."

"It still won't snow."

"You know what I mean."

"Honey, you'll be back in the lab in a few hours. Save the world then."

C. N. Simms is a jack-of-all-trades whose former careers span corporate and social divides. He has no current plans to create a genome. 